The relevance of these findings to problems of tissue transplantation, in particular graft rejection, is mentioned and discussed. The simplicity of the method of endolymphatic infusion in producing a lymphopenia that may last up to five months makes it a possible alternative to other methods of immunosuppression, particularly in the early phase of tissue transplantation.

We are indebted to the radioisotope and physics departments of St. Thomas's Hospital, in particular to Dr. T. M. D. Gimlette and Mr. W. F. Clapham, for advice in the preparation of this paper. Also we are grateful to Mr. D. L. Rutt for technical assistance and to Mr. T. W. Brandon, phatographic department, and Miss Dewe, medical artist, for help with the illustrations.

\section{REFERENCES}

Fortner, J. G., Booher, R. J., and Pack, G. T. (1964). Surgery, 55, 485 Hine, G. J., and Brownell, G. L. (1956). Radiation Dosimetry. New York.
Hume, D. M. (1961). The Year Book of Urology, edited by W. W. Scott, Chicago. Quoted in Lancet, 1962, 2, 385.

Jantet, G. H., Edwards, J. M., Gough, M. H., and Kinmonth, J. B. (1964). Brit. med. Э., 2, 904.

Lajtha, L G. Lewis, C. L., Oliver, R., Gunning, A. J., Sharp, A. A., and Callender, S. (1962). Lancet, 1, 353.

McGregor, D. D., and Gowans, J. L. (1963). 7. exp. Med., 117, 303.

Mowbray, J. F., Cohen, S. L., Doak, P. B., Kenyon, J. R., Owen, K., Percival, A., Porter, K. A., and Peart, W. S. (1965). Brit. med. ₹., 2, 1387 .

Parsons, F. M. (1966). Personal communication.

Raper, F. P., Fox, M., Markland, A. C., and Anderson, C. K. (1964). Transplantation, 2, 162.

Thomas, E. D., Epstein, R. B., Eschbach, J. W., Prager, D., Buckner, C. D., and Marsaglia, G. (1965). New Engl. F. Med., 273, 6.

Tilak, S. P., and Howard, J. M. (1964). Surg. Forum, 15, 160.

Wheeler, J. R., White, W. F., and Calne, R. Y. (1965). Brit. med. J., 2, 339 .

Woodruff, M. F. A. (1960). The Transplantation of Tissues and Organs, p. 95 Illinois.

\title{
Observations on the Absorption of Oral Betamethasone 17-Valerate and its Therapeutic Value in Ulcerative Colitis
}

\author{
M. FRIEDMAN,* M.D., M.R.C.P.ED. ; J. FLETCHER, † M.A., M.B., M.R.C.P. ; J. M. HINTON, † M.A., B.M., M.R.C.P. \\ J. E. LENNARD-JONES, †§ M.A., M.D., M.R.C.P. ; J. J. MISIEWICZ,†§ M.B., B.SC. \\ J. A. PARRISH, $+\|$ M.D., M.R.C.P.
}

Brit. med. F., 1967, 1, 335-337

Oral betamethasone 17-valerate (Betnovate) has been put forward as an effective treatment for ulcerative colitis which has the great advantage that it causes neither adrenal suppression nor the usual side-effects of steroid therapy (Morton Gill et al., 1965). A steroid which is not absorbed after oral administration but which is topically active in the large intestine would be a major advance in the treatment of colitis. We have therefore studied the absorption of betamethasone 17-valerate in normal subjects by measuring its effect on adrenal function. In patients with ulcerative colitis we have studied its use as a treatment and correlated the clinical results with studies of adrenal function.

\section{Methods}

Heparinized blood samples were collected between 9 and 10 a.m. The plasma was separated within 30 minutes of venepuncture and stored at $-4^{\circ}$ C. until the estimations were performed. The plasma cortisol was measured as free plasma total 11-hydroxycorticosteroids by a modification of the fluorometric method of Mattingly (1962) (Black and Friedman, 1965). With this method the normal range of plasma cortisol level at 9 a.m. is $8-28 \mu \mathrm{g} . / 100 \mathrm{ml}$.

\section{Studies in Normal Subjects}

Studies were carried out on seven normal subjects who were without any previous gastrointestinal symptoms. They were members of the hospital staff, three men and four women, aged 24 to 39 years.

\footnotetext{
- Paediatric Departments, University College Hospital and the Whittington Hospital, London. † St. Mark's Hospital, London.

$\$$ In receipt of a grant from the Medical Research Council.

Member of the Medical Research Council Gastroenterology Research Unit, Central Middlesex Hospital, London N.W.10.

H Physician, Mayday Hospital, Croydon, Surrey.
}

Five studies were performed (Fig. 1). In the first two each subject took by mouth in divided six-hourly doses for 48 periods (A) $2 \mathrm{mg}$. daily of dexamethasone and (B) $2 \mathrm{mg}$. daily of betamethasone free alcohol. In a third study (C) each subject took 2,4 , and $8 \mathrm{mg}$. daily of betamethasone 17-valerate in divided six-hourly doses for consecutive 48-hour periods. In a fourth study (D) the two subjects in whom adrenal suppression did not occur on $8 \mathrm{mg}$. daily of betamethasone 17-valerate in the third study $(\mathrm{C})$ were given $12 \mathrm{mg}$. daily in divided doses six-hourly for 48 hours. In a fifth study (E) three subjects were given $8 \mathrm{mg}$. daily of betamethasone 17-valerate in divided doses six-hourly for $\mathbf{4 8}$ hours. The studies were not carried out in any fixed order and at least a week was allowed to elapse between each one. The plasma cortisol was measured before and after each 48-hour period, the last blood specimen being taken within three hours of the final dose.

\section{Studies in Patients with Ulcerative Colitis}

Twenty-seven outpatients with ulcerative colitis were treated. Preliminary clinical observations were made in 17 patients who were given 4 or $8 \mathrm{mg}$. of betamethasone 17 -valerate daily by mouth in divided doses. Ten further patients were treated with $8 \mathrm{mg}$. daily for two to four weeks. In these ten patients the clinical results were correlated with plasma cortisol levels measured before treatment, and at two and/or four weeks. The patients were asked to take the tablets four times daily and to ensure that one was taken on the morning of the visit to the clinic. At each attendance they were asked whether any tablets had been missed. No direct inquiry was made about sideeffects. The results of treatment were assessed symptomatically and sigmoidoscopically, as described in previous trials (Baron et al., 1962b). A remission is defined as complete freedom from symptoms with a non-haemorrhagic non-friable mucosa on sigmoidoscopy. 


\section{Results of Adrenal Function Studies}

\section{Normal Subjects}

The details of the studies on normal subjects are shown in Fig. 1.

Dexamethasone $2 \mathrm{mg}$. daily (Fig. $1 \mathrm{~A}$ ).-In all six subjects the plasma cortisol level fell to below $2.4 \mu \mathrm{g} . / 100 \mathrm{ml}$. This finding is similar to that in 86 normal subjects where the level always fell to below $3 \mu \mathrm{g} . / 100 \mathrm{ml}$. (Friedman, unpublished data). For the purposes of this study suppression of adrenal function is taken as a level of less than $3 \mu \mathrm{g} . / 100 \mathrm{ml}$.

Betamethasone Free Alcohol $2 \mathrm{mg}$. daily (Fig. $1 \mathrm{~B}$ ).-In all seven subjects the level fell to below $2.8 \mu \mathrm{g} . / 100 \mathrm{ml}$.

Increasing doses of betamethasone 17-valerate: $2 \mathrm{mg}$., $4 \mathrm{mg}$., and $8 \mathrm{mg}$. daily (Fig. $1 \mathrm{C}$ ).-Plasma cortisol levels tended to decrease as the dose of betamethasone 17-valerate was increased. Suppression of adrenal function did not occur at $2 \mathrm{mg}$. and $4 \mathrm{mg}$. daily, but did occur in four out of six subjects at $8 \mathrm{mg}$. daily. In one subject the drug was withdrawn because of vomiting and dyspepsia at a dose of $4 \mathrm{mg}$. daily, and at this stage suppression had not occurred.

Betamethasone 17-valerate $12 \mathrm{mg}$. daily (Fig. $1 \mathrm{D}$ ).-The two subjects in whom adrenal suppression did not occur with betamethasone 17-valerate $8 \mathrm{mg}$. daily in experiment $\mathrm{C}$ were given $12 \mathrm{mg}$. daily in divided doses in a separate experiment. At this dose adrenal suppression occurred in both subjects.

Betamethasone 17-valerate $8 \mathrm{mg}$. daily (Fig. $1 \mathrm{E}$ ). - Three subjects were given $8 \mathrm{mg}$. daily in divided doses for a single days were similar to those obtained when increasing doses were given over six days.

Side-effects. - Three of the seven normal subjects complained of dyspepsia at daily doses of 2,4 , and $8 \mathrm{mg}$. respectively. In one subject vomiting also occurred and the experiment was stopped.

\section{Ten Patients with Ulcerative Colitis}

The results are shown in Fig. 2 and Table II. The blood cortisol level tended to fall after treatment with betamethasone 17 -valerate $8 \mathrm{mg}$. daily for two or four weeks. In 3 of the 10 patients the level fell to less than $3 \mu \mathrm{g} . / 100 \mathrm{ml}$., indicating adrenal suppression. There was no apparent correlation beperiod of 48 hours on a separate occasion. The results after two

tween the clinical response to treatment and the changes in blood cortisol level.

\section{Clinical Results}

Pilot Study with Various Doses of Betamethasone 17-Valerate

The 17 outpatients studied in this pilot trial were either in their first attack or in a relapse of proctocolitis of moderate severity; they would otherwise have been treated with oral prednisone or with oral sulphasalazine and steroid enemas. Though an attempt was made to exclude patients who had recently had either oral or rectal steroid therapy, this was not a strict criterion for entry into the pilot study as it was in the subsequent trial. Patients with mild or very severe disease were not included. Five patients received $4 \mathrm{mg}$. daily, of whom one improved; five received $4 \mathrm{mg}$. daily initially and then $8 \mathrm{mg}$. daily after two weeks because of failure to respond to the lower dosage, but no patient improved ; and seven patients, of whom three improved, received $8 \mathrm{mg}$. daily from the beginning. Six of seven patients who had never previously had oral steroids and five of eight patients who had earlier responded well to oral steroids failed in this study to respond to betamethasone 17-valerate.

Other factors such as age, sex, extent of disease, and length of history of colitis had no apparent effect on patients' response (Table I).

\section{Trial of $8 \mathrm{mg}$. Daily of Betamethasone 17-Valerate}

Our impression during the pilot study had been that $8 \mathrm{mg}$. of betamethasone 17-valerate daily might be of benefit, and therefore a stricter trial with this dose was designed.

\begin{tabular}{|c|c|c|c|c|c|c|c|c|c|c|c|c|}
\hline \multirow{2}{*}{\multicolumn{2}{|c|}{$\begin{array}{l}\text { No. of } \\
\text { Patients }\end{array}$}} & \multicolumn{2}{|c|}{ Sex } & \multicolumn{3}{|c|}{ Age } & \multicolumn{3}{|c|}{$\begin{array}{c}\text { Extent of } \\
\text { Disease }\end{array}$} & \multicolumn{3}{|c|}{$\begin{array}{c}\text { Length of } \\
\text { History (Years) }\end{array}$} \\
\hline & & M. & F. & $20-39 \mid$ & $\mid 40-59$ & $60+$ & $\mathbf{E}$ & $\mathbf{L}$ & D & 1 & $1-10$ & 10 \\
\hline \multirow{2}{*}{$\begin{array}{l}\text { Improved } \\
\text { No change } \\
\text { or worse }\end{array}$} & 4 & 2 & 2 & 0 & 3 & 1 & 2 & 0 & 2 & 0 & 1 & 3 \\
\hline & 13 & 7 & 6 & 5 & 3 & 5 & 0 & 3 & 10 & 2 & 9 & 2 \\
\hline Total & 17 & 9 & 8 & 5 & 6 & 6 & 2 & 3 & 12 & 2 & 10 & 5 \\
\hline
\end{tabular}
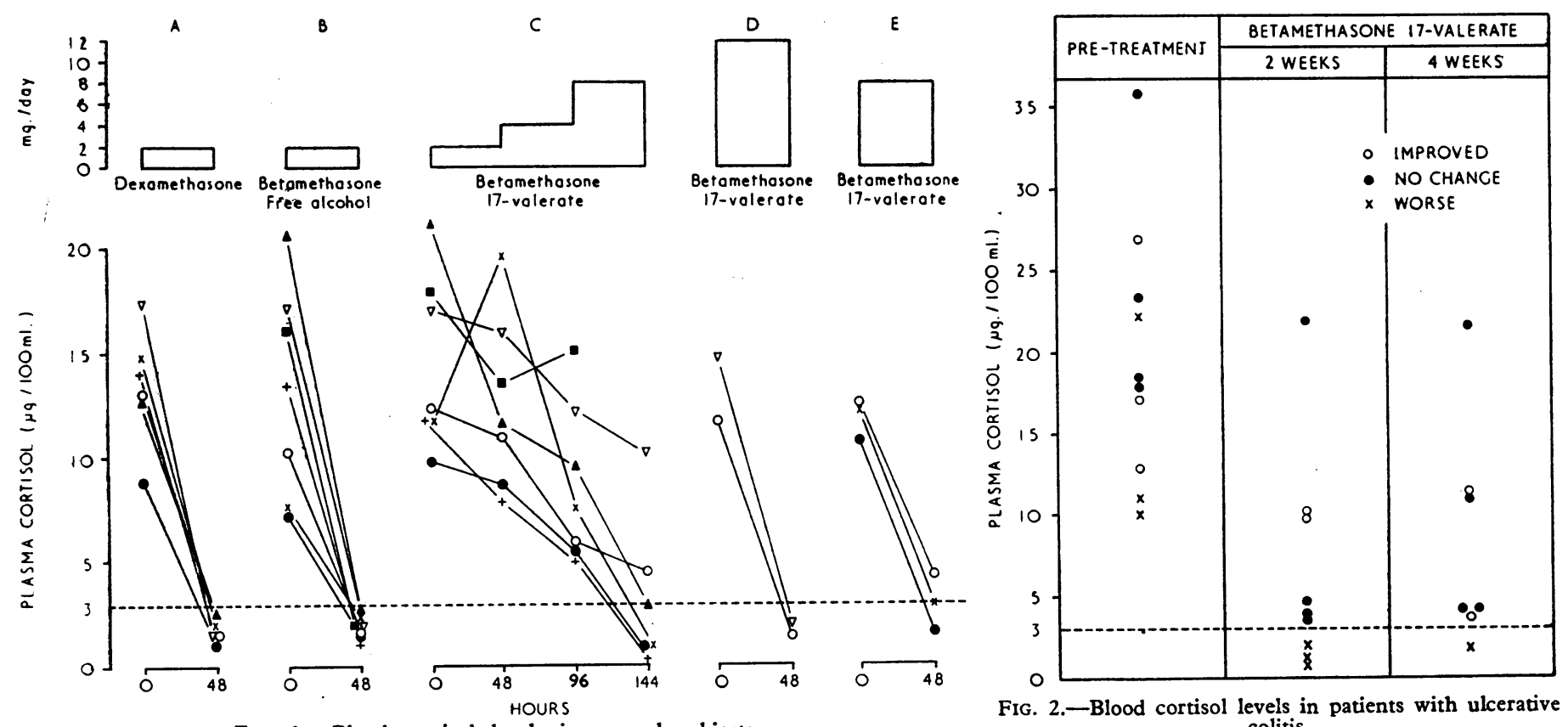

FIG. 2.-Blood cortisol levels in patients with ulcerative colitis.

Fig. 1.-Blood cortisol levels in normal subjects 
TABLE II.-Clinical and Biochemical Data of Ten Patients Treated with Betamethasone 17-Valerate, 8 mg. daily, and Their Subsequent Course

\begin{tabular}{|c|c|c|c|c|c|c|c|c|c|c|c|c|c|c|}
\hline \multirow{3}{*}{$\begin{array}{l}\text { Case } \\
\text { No. }\end{array}$} & \multirow{3}{*}{ Age } & \multirow{3}{*}{ Sex } & \multirow{3}{*}{$\begin{array}{l}\text { Extent } \\
\text { of } \\
\text { Disease }\end{array}$} & \multirow{3}{*}{$\begin{array}{l}\text { Length } \\
\text { of } \\
\text { History }\end{array}$} & \multirow{3}{*}{$\begin{array}{l}\text { Time } \\
\text { since Last } \\
\text { Relapse }\end{array}$} & \multicolumn{4}{|c|}{ Response } & \multirow{3}{*}{$\begin{array}{c}\text { Final } \\
\text { Overall } \\
\text { Assess- } \\
\text { ment }\end{array}$} & \multirow{2}{*}{\multicolumn{3}{|c|}{$\begin{array}{c}\text { Plasma Cortisol* } \\
(\mu \mathrm{g} .100 \mathrm{ml} .)\end{array}$}} & \multirow{3}{*}{$\begin{array}{l}\text { Subsequent } \\
\text { Respoinset }\end{array}$} \\
\hline & & & & & & \multicolumn{2}{|c|}{ Symptoms } & \multicolumn{2}{|c|}{ Sigmoidoscopy } & & & & & \\
\hline & & & & & & $2 / 52$ & $4 / 52$ & $2 / 52$ & $4 / 52$ & & Start & $2 / 52$ & $4 / 52$ & \\
\hline 1 & 46 & $\mathbf{F}$ & D & 20 years & Continuous & NC & IMP & NC & NC & Improved & $12 \cdot 8$ & $9 \cdot 8$ & - & - \\
\hline $\begin{array}{l}2 \\
3 \\
4\end{array}$ & $\begin{array}{l}58 \\
51 \\
53\end{array}$ & $\underset{\mathbf{M}}{\mathbf{F}}$ & $\begin{array}{l}\mathrm{L} \\
\mathrm{D} \\
\mathbf{D}\end{array}$ & $\begin{array}{l}6 \text { weeks } \\
3 \% \\
6 \%\end{array}$ & 三 & $\begin{array}{l}\text { NC } \\
\text { IMP } \\
\text { NC }\end{array}$ & $\begin{array}{l}\text { IMP } \\
\text { IMP } \\
\text { NC }\end{array}$ & $\begin{array}{l}\text { NC } \\
\text { NC } \\
\text { NC }\end{array}$ & $\begin{array}{l}\text { IMP } \\
\text { NC } \\
\text { NC }\end{array}$ & No" change & $\begin{array}{l}17 \cdot 2 \\
27 \cdot 0 \\
36 \cdot 0\end{array}$ & $\begin{array}{l}\overline{10 \cdot 0} \\
22 \cdot 0\end{array}$ & $\begin{array}{r}11 \cdot 2 \\
3 \cdot 8 \\
21 \cdot 6\end{array}$ & $\frac{\overline{-}}{\text { Improved with }}$ \\
\hline 5 & 63 & $\mathbf{M}$ & $\mathrm{D}$ & 5 & - & NC & NC & NC & NC & & $18 \cdot 4$ & $3 \cdot 8$ & $10 \cdot 8$ & Improved with \\
\hline 6 & 47 & $\mathbf{M}$ & E & 29 years & 2 years & NC & NC & NC & IMP & $"$ & $18 \cdot 0$ & $4 \cdot 8$ & $4 \cdot 2$ & Improved with \\
\hline 7 & 31 & $\mathbf{F}$ & $\mathrm{D}$ & 1 year & - & NC & NC & NC & NC & $"$ & $23 \cdot 6$ & $4 \cdot 0$ & $4 \cdot 2$ & Improved with \\
\hline 8 & 53 & $\mathbf{M}$ & $\mathbf{L}$ & 8 years & 3 years & NC & $\mathbf{w}$ & NC & NC & Worse & $11 \cdot 0$ & $1 \cdot 0$ & - & $\begin{array}{l}\text { Improved with } \\
\text { oral Pred. } 30\end{array}$ \\
\hline 9 & 25 & $\mathbf{M}$ & D & 3 months & - & NC & $\mathbf{W}$ & NC & NC & ", & $10 \cdot 0$ & $1 \cdot 2$ & $2 \cdot 0$ & $\begin{array}{l}\text { Slow response to } \\
\text { oral Pred. } 30\end{array}$ \\
\hline 10 & 39 & $\mathbf{F}$ & $\mathbf{L}$ & 5 years & 2 years & $\mathbb{W}$ & $\mathbf{w}$ & NC & NC & ", & $22 \cdot 2$ & $2 \cdot 0$ & - & $\begin{array}{l}\text { Slow response to } \\
\text { oral Pred. } 30\end{array}$ \\
\hline
\end{tabular}

IMP $=$ Improved. $\quad \mathrm{NC}=$ No change. $\mathrm{W}=$ Worse

* No figures are available at four weeks in Case 1 because the patient did not arrive on the correct day, and in Cases 8 and 10 because treatment with betamethasone
(1) $\dagger$ P21P $=$ Prednisolone-21-phosphate retention enemas. $\mathrm{S}=$ Oral sulphasalazine. Oral Pred. $30=30 \mathrm{mg}$. of prednisone daily by mouth.

Of the ten outpatients in this trial six were in their first attack of colitis, the remainder in a relapse. The disease in all cases was of moderate severity and would otherwise have been treated with oral prednisone or oral sulphasalazine and steroid enemas. Eight of the ten patients had never received either oral or rectal steroids before the trial and the other two patients had not received steroids for two years.

Three of the ten patients improved with this treatment, but none of these was in complete remission at four weeks. None of the patients spontaneously complained of side-effects. The seven patients who failed to improve with betamethasone 17 valerate all improved subsequently on oral prednisone $30 \mathrm{mg}$. daily or on oral sulphasalazine and prednisolone-21-phosphate retention enemas, though in two the response was very slow, and one of these required admission to hospital (Table II).

\section{Discussion}

Adrenal suppression occurred in all the normal subjects to whom a dose of 8 or $12 \mathrm{mg}$. of betamethasone 17-valerate could be given. The dose of betamethasone 17-valerate required to cause suppression was, weight for weight, greater than that of betamethasone free alcohol. In three of the seven normal subjects dyspepsia occurred at doses lower than those which caused suppression.

Betamethasone 17-valerate would be a therapeutic advance if it brought about an improvement in colitis at a dose lower than that which caused adrenal suppression. However, in this trial the clinical results were disappointing, even though suppression occurred in 3 of the 10 patients whose adrenal function was studied. In previous trials at this hospital (LennardJones et al., 1960 ; Baron et al., 1962b) it was found that of 38 patients who had an acute relapse of ulcerative colitis treated with a placebo four were in remission, nine were improved, and 25 were unchanged or worse after three to four weeks. In contrast, of 40 patients in acute relapse treated with oral prednisone $40 \mathrm{mg}$. daily (Baron et al., 1962a ; Misiewicz et al., 1964) 26 were in remission and five were improved after only two weeks. Of 20 patients in acute relapse treated with prednisolone-21-phosphate enemas (Misiewicz et al., 1964) 10 were in remission and six improved after two weeks' therapy. In this trial betamethasone 17 -valerate $8 \mathrm{mg}$. daily produced improvement in only 6 out of 17 patients after four weeks and none was in remission. The results with smaller doses were even less encouraging.

It can be argued that an orally administered drug which is not absorbed can hardly be expected to exert much effect upon the inflamed dista! colon. $X$-ray studies have shown that in ulcerative colitis the diseased bowel is usually empty (Young, 1963). This suggests that there will be little contact between the drug in the faeces and the diseased mucosa. However, this type of therapy may be applicable to small-bowel mucosal disease.

Our studies show that, although there is probably no adrenal suppression at $2 \mathrm{mg}$. daily, betamethasone 17-valerate by mouth causes suppression in normal subjects at a dose of 8-12 mg. daily, demonstrating that the drug is absorbed from the gut. When used in the treatment of ulcerative colitis at a dose of $8 \mathrm{mg}$. daily the clinical effect appeared to be no better than a placebo, even though adrenal suppression occurred in 3 out of 10 patients. In our experience oral betamethasone 17-valerate is of no value for the treatment of ulcerative colitis in the dose employed in this study.

\section{Summary}

It has been suggested that betamethasone 17 -valerate is an effective treatment for ulcerative colitis which causes neither adrenal suppression nor other steroid side-effects. However, adrenal suppression was demonstrated in all of six normal subjects taking 8 or $12 \mathrm{mg}$. daily of the drug by mouth, showing that absorption does occur. In a clinical study of 27 patients with an acute attack of ulcerative colitis the results of treatment with betamethasone 17 -valerate $8 \mathrm{mg}$. daily were disappointing. Adrenal function was studied in 10 of these patients, and in three of them suppression occurred. We conclude that in the dose used in this study oral betamethasone 17 -valerate is not a satisfactory treatment for ulcerative colitis.

We thank Dr. F. Avery Jones for his help and support; Sister D. Christie for her help in the clinic; and Glaxo Laboratories for supplying the betamethasone 17-valerate used in the trial.

Requests for reprints should be sent to J. E. Lennard-Jones, St. Mark's Hospital, City Road, London E.C.1.

\section{REFERENCES}

Baron, J. H., Connell, A. M., Kanaghinis, T. G., Lennard-Jones, J. E., and Jones, F. A. (1962a). Brit. med.' F., 2, 441. Lennard-Jones, J. E., and Jones, F. A. (1962b). Lancet, 1, Black, S., and Friedman, M. (1965). Brit. med. 7., 1, 562.

Gill, A. М̈., Otaki, A. T., Daly, J. R., and Spencer-Peet, J. (1965). Ibid.,

Lennard-Jones, J. E., Longmore, A. J., Newell, A. C., Wilson, C. W. E., and Jones, F. A. (1960). Gut, 1, 217

Mattingly, D. (1962). I. clin. Path., 15, 374.

Misiewicz, J. J., Connell, A. M., Lennard-Jones, J. E., and Jones, F. A. (1964). Proc. roy. Soc. Med., 57, 561.

Young, A C. (1963). Ibid., 56, 491. 